ELORE (ISSN 1456-3010), vol. $16-2 / 2009$.

Julkaisija: Suomen Kansantietouden Tutkijain Seura ry.

[http://www.elore.fi/arkisto/2_09/kirjallisuus_hovi_tuomas_2_09.pdf]

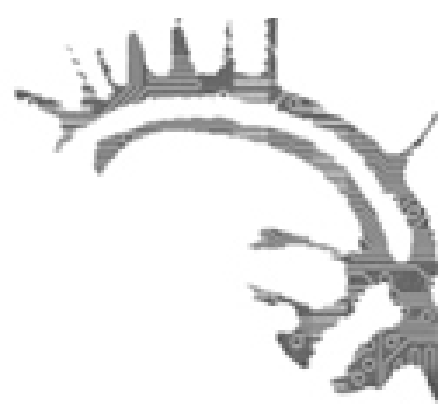

\title{
KiRJA-ARVIO:
}

\section{TURISMIN KUltTUURIPERINTÖÄ AhVEnanMaAlla}

Lindqvist, Yrsa (toim.) 2008: Tradition och turism på Aland. At använda kulturarvet. Helsinki: Svenska litteratursällskapet $i$ Finland. 240 sivua.

\section{$\underline{\text { Tuomas Hovi }}$}

Perinnettä ja historiaa hyödynnetään matkailuteollisuudessa ympäri maailmaa. Arvioiden mukaan kulttuuri, perinne ja kulttuuriperintö ovat osatekijöitä melkein puolessa kaikista ulkomaille suunnatuissa matkoissa koko maailmassa. Kulttuuri- ja perinnematkailun lisääntyessä tulevat kulttuuriperintöön liittyvät kulttuuripoliittiset kysymykset tärkeiksi. Mikä perinnekulttuurin tai historian osa-alue nähdään tärkeäksi tuoda esille ja nostaa kulttuuriperinnöksi ja mikä ei?

Yrsa Lindqvistin toimittama Tradition och turism på Aland. Att använda kulturarvet käsittelee kulttuuriin, perinteeseen, kulttuuriperintöön ja -matkailuun liittyviä kysymyksiä Ahvenanmaalla. Teos on tulos vuonna 2005 alkaneesta perinteenkeruuhankkeesta, jonka tarkoituksena oli tutkia perinteen ja turismin suhdetta Ahvenanmaalla. Kirjassa esitellään ne historian, perinteen ja kulttuurin osat, jotka nähdään Ahvenanmaalle tärkeinä ja jotka halutaan tuoda matkailun avulla esiin paikallisidentiteettiä vahvistavaksi kulttuuriperinnöksi. Teos koostuu yhteensä kymmenestä Ahvenanmaan matkailua käsittelevistä artikkelista. Kirjassa käsitelläänkin Ahvenanmaan matkailun ja kulttuuriperinnön suhdetta monipuolisesti 1800-luvun lopusta nykypäivään asti.

\section{AhVEnanmaAn KUltTUURIPERINTö}

Avausartikkelin jälkeen kirjassa käsitellään perinteen ja matkailun suhdetta tapaus- ja aihekohtaisesti. Vaikka artikkelien kohteet eroavat toisistaan, toimivat Ahvenanmaalle ominaisen kulttuurin ja perinteen etsiminen ja esiintuominen punaisena lankana läpi 


\section{TuOMAS Hovi}

kirjan. Tämän lisäksi kirjassa käsitellään perinneturismin tutkimuksessa yleisiä aitouteen ja autenttisuuteen liittyviä oletuksia sekä nostalgian suhdetta perinnematkailuun. Kirjan artikkeleissa esitellyt kohteet ja aihepiirit voidaan jakaa karkeasti kolmeen osaan, jotka samalla ikään kuin kokoavat ne perinteen, kulttuurin ja historian osat, jotka muodostavat Ahvenanmaan kulttuuriperinnön: historia, meri ja paikallisperinne. Johdantona toimivan avausartikkelin jälkeen seuraavat viisi artikkelia käsittelevät historiaa: Mikael Korhosen artikkeli kertoo Ahvenanmaan turismin historiasta, Carola Ekremin kolme artikkelia käsittelevät Ahvenanmaan kirkkoja taidehistorioitsija Emil Nervanderin kuvaamina, yleisemmin turistikohteina sekä 1900-luvun alussa kerätyn tarinaperinteen kautta. Seuraavat kaksi artikkelia liittyvät mereen ja meren merkitykseen ahvenanmaalaisessa kulttuurissa. Marika Rosenström kuvaa merellistä kulttuuriperintöä ja sen hyödyntämistä Ahvenanmaan turismissa. Meta Sahlströmin artikkeli puolestaan kuvaa elämysmatkailua lähinnä yhden ahvenanmaalaisille tärkeän kohteen, Kobba Klintarin entisen luotsiaseman, kautta. Kirjan kolmannen aihealueen muodostavat Yrsa Lindqvistin ahvenanmaalaista käsityötä ja Monica Ståhls-Hindsbergin kotiseutumuseoita käsittelevät artikkelit. Yhteistä näille kahdelle artikkelille on niiden kohteen näkeminen paikallisen kulttuurin ja perinteen kannattajina. Ahvenanmaalainen käsityö kuvataan tärkeäksi Ahvenanmaan omakuvan kannalta, ja sen nähdään olevan jotain autenttisesti ahvenanmaalaista. Kotiseutumuseot puolestaan antavat turistille mahdollisuuden tutustua ja kokea, minkälaista omavaraistalouden aikana Ahvenanmaalla oli elää. Samalla kotiseutumuseot toimivat oman identiteetin vahvistajina paikallisille ihmisille.

Kirjan viimeisenä oleva Anne Bergmanin ahvenanmaalaisia opastettuja kiertoajeluja kuvaava artikkeli kokoaa kirjan muiden artikkelien aihepiirit yhteen. Bergman osallistui itse kolmelle opastetulle kiertoajelulle ja tutustui myös omin päin erinäisiin opastettuihin turistinähtävyyksiin. Bergmanin vierailemiin kohteisiin kuuluivat muun muassa Bomarsundin linnoitus, Kastelholman linna, Jan Karlsgården ulkoilmamuseo, Finströmin ja Föglön kirkot, museolaiva Pommern, merenkulkumuseo, kivikauden kylä Saltvikissa, keskiaikatalo Jomalassa ja Ahvenanmaan museo Maarianhaminassa. Nämä kohteet toivat esiin Ahvenanmaan historiaa, merellistä ympäristöä sekä paikallisperinnettä ja identiteettiä - toisin sanoen aihepiirejä, jotka muodostavat Ahvenanmaan kulttuuriperintöä.

\section{HYÖDYNNETTY KULTTUURIPERINTÖ IDENTITEETTIÄ LUOMASSA}

Se kulttuuriperintö, jota Ahvenanmaan turismissa hyödynnetään ja jota kirjassa tuodaan esiin, liittyy Ahvenanmaan historiallisiin kohteisiin, mereen sekä luonnonelementtinä että kulttuuria ja identiteettiä muovaavana tekijänä sekä ahvenanmaalaiseen käsityö- ja paikallisperinteeseen. Yksi aihepiiri, joka jätetään kirjassa kokonaan vaille huomiota ja joka olisi siihen hyvin sopinut, on ruokaan liittyvä perinne. Tämä puute tosin tiedostetaan ja tunnustetaan kirjan ensimmäisessä artikkelissa lähinnä ajan- ja resurssienpuutteesta johtuvaksi tutkimusvalinnaksi. Eräs mielenkiintoinen teema, joka ilmenee kirjan useammassa artikkelissa, on matkailussa esille tuodun kulttuuriperinnön merkitys ahvenanmaalaisille itselleen. Ahvenanmaa on sen historiasta ja maantieteelli- 
sestä sijainnista johtuen ikään kuin idän ja lännen, Suomen ja Ruotsin välissä. Vaikka Ahvenanmaa on osa Suomea, esiintyy Ahvenanmaan kulttuuri ja identiteetti Suomesta ja suomalaisuudesta erillisenä. Ahvenanmaan turistikohteet ja museot vaikuttavatkin olevan lähes yhtä tärkeitä, ellei jopa tärkeämpiä, ahvenanmaalaisille itselleen kuin turisteille. Ahvenanmaalainen kulttuuriperintö toimii matkailussakin nimenomaan ahvenanmaalaisen identiteetin tuottajana ja ylläpitäjänä.

\section{LOPUKSI}

Tradition och turism på Aland on mitä ilmeisimmin niin sanotulle suurelle yleisölle tarkoitettu teos. Se on helppolukuinen, hyvin taitettu ja sisältää paljon kuvia. Helppolukuisuutta lisää myös viitteiden puuttuminen. Toisaalta juuri viitteiden puuttuminen tekee kirjasta tutkimuskirjallisuutena mielestäni haastavan. Kirjan lopussa on jaoteltu kussakin artikkelissa käytetyt lähteet, mutta tarkempien viitteiden ja sivunumeroiden puuttuminen tekee tekstissä mainittujen lainauksien tarkistamisen liian työlääksi. Kokonaisuutena kirja antaa kuitenkin hyvän ja monipuolisen kuvan Ahvenanmaan matkailusta 1800-luvun lopusta nykypäivään. Kirjassa myös tuodaan selkeästi esiin se, miten ja mitä perinnettä Ahvenanmaan matkailussa ja sen mainonnassa on eri aikoina hyödynnetty.

Filosofian maisteri Tuomas Hovi on folkloristiikan jatko-opiskelija Turun yliopistossa. 